\title{
Ebeveynlerin Dental Tedavide Genel Anestezi Öncesi Anksiyete Durumu ve Genel Anestezi Hakkında Bilgi Düzeylerinin Ölçülmesi*
}

\section{Measuring Parental Anxiety Before General Anesthesia in Dental Treatment and Their Knowledge about} General Anesthesia

\author{
Ayşe Özcan Küçüki, Ebru Delikanii, Hüsniye Gümüşiii
}

'Dr. Öğr. Üyesi, Mersin Üniversitesi, Diş Hekimliği Fakültesi, Ağız, Diş ve Çene Cerrahisi AD, https://orcid.org/0000-0002-8289-8066 iiDr.Öğr.Üyesi, Nuh Naci Yazgan Üniversitesi, Diş Hekimliği Fakültesi, Çocuk Diş Hekimliği AD,https://orcid.org/0000-0003-1624-3392 iiiDr. Öğr. Üyesi, Erciyes Üniversitesi, Diş Hekimliği Fakültesi, Çocuk Diş Hekimliği AD, https://orcid.org/0000-0003-4064-337X

\section{öz}

Amaç: Bu çalışmanın amacı, genel anestezi altında dental tedavileri yapılacak çocukların ebeveynlerinin genel anestezi ile ilgili bilgi düzeylerini ve preoperatif anksiyete düzeylerini değerlendirmektir.

Yöntem: Çalışmaya Erciyes Üniversitesi'ne dental tedaviler için başvuran ve genel anestezi endikasyonu koyulan çocuk hastaların ebeveynlerini dâhil edilmiştir. Çocukları ameliyathaneye alındıktan hemen sonra ebeveynlerin bilgi düzeyleri modifiye Standart Anestezi Öğrenme Testi (SALT) ile anksiyete düzeyleri modifiye Vizüel Analog Skala (VAS) ile değerlendirilmiştir.

Bulgular: Anketi 148 kadın (\%63), 87 erkek (\%37) olmak üzere toplam 235 ebeveyn tamamladı. Katılımcılar en fazla 31-40 yaş aralığında idi $(\% 54,9)$. Eğitim durumlarına göre ebeveynlerin çoğunluğunu lise mezunları oluşturuyordu $(\% 39,1)$. Ebeveynlerin \%64,3'ünün daha önceden anestezi deneyimi vardı. Ebeveynlerinin anksiyete skorları ile genel anestezi deneyimi, eğitim düzeyi, çocuk sayısı arasında anlamlı bir fark bulunamadı $(p>0,05)$. Kadınların anksiyete düzeyi erkeklere göre anlamlı olarak daha yüksekti $(p<0,05)$. 50 yaş üzeri ebeveynlerin anksiyete düzeyi gençlere göre anlamlı olarak daha düşüktü $(p<0,05)$. Ebeveynlerin $\% 56,6$ 'sı genel anestezinin nasıl başlatıldığını ve $\% 55,7$ 'si genel anestezi öncesi damar yolunun neden açıldığını bilmekteydi. Ayrıca katılımcıların sadece \%35,7'si anestezi uzmanının doktor olduğunun farkındaydı.

Sonuç: Bu çalışma ebeveynlerin pediatrik dental tedavilerde sıkça uygulanan genel anestezi uygulamaları ile ilgili bilgilerinin yeterli olmadığını ve değişen düzeylerde preoperatif anksiyeteye sahip olduklarını göstermiştir. Bu nedenle sağlık çalışanları ameliyat öncesi ebeveynlerin korku ve endişelerini gidermek için daha fazla bilgilendirme yapmalıdır.

Anahtar Kelimeler: Ebeveyn anksiyetesi, Genel anestezi, Anket, Bilgi, Pediatrik dental tedavi

ABSTRACT

Objective: The aim of this study is to evaluate the knowledge and preoperative anxiety of the parents toward dental treatments under general anesthesia (GA).

Materials and Methods: Parents of children who referred to Erciyes University for dental treatments under GA were included in the study. Immediately after children entered the operation room, the knowledge of the parents were evaluated with the modified Standard Anesthesia Learning Test and their anxiety levels with the Visual Analogue Scale.

Results: A total of 235 parents, 148 female (63\%) and 87 male (37\%), completed the questionnaire. Participants are mostly between the ages of 31-40 (54.9\%). The majority of the parents were high school graduates (39.1\%). $64.3 \%$ of the parents had previous anesthesia experience. No significant difference was found between the anxiety scores of the parents and the experience of GA, education level, and the number of children $(p>0.05)$. Anxiety of female was significantly higher than male $(p<0.05)$. The anxiety of the parents over the age of 50 was significantly lower than the young parents $(p<0.05)$. $56.6 \%$ of the parents knew how GA was initiated and $55.7 \%$ knew why an intravenous line was started before GA. Additionally, only $35.7 \%$ of the participants were aware that the anesthesiologist was a doctor.

Conclusion: This study showed that the parents had insufficient knowledge about GA, which is frequently used in pediatric dental treatments, and they have varying levels of preoperative anxiety. Therefore, healthcare professionals should provide more information before surgery to alleviate parents' fear and anxiety.

Keywords: Parental anxiety, General anesthesia, Questionnaire, Knowledge, Pediatric dental treatment

\footnotetext{
*Lokman Hekim Dergisi, 2021; 11 (2): 391-399

DOI: $10.31020 /$ mutftd.912278

e-ISSN: 1309-8004, ISSN 1309-761X

Geliş Tarihi-Received: 09 Nisan 2021; Kabul Tarihi - Accepted: 03 Mayıs 2021

Iletişim - Correspondence Author: Ayşe Özcan Küçük <ayseozcan89@hotmail.com>

Etik Kurul Onayı: Mersin Üniversitesi Klinik Araştırmalar Etik Kurulu (2018/47)
} 


\section{Giriş}

Günümüzde dental işlemler için gerçekleştirilen genel anestezi uygulamaları giderek yaygınlaşmaktadır. Illetişim kurulamayan, uyumsuz, aşırı korkan ve aşırı kaygılı, fiziksel, duygusal, mental ya da medikal engeli bulunan, kraniofasial anomali ve girişimsel cerrahi işlemler gerektiren ve sedasyon veya genel anestezi sayesinde medikal ve fiziksel riskin azaltılabileceği çocuk hastalar için dental problemlerin tedavisinde sıklıkla genel anesteziye intiyaç duyulmaktadır. ${ }^{1-3}$

Dental rehabilitasyon için gerçekleştirilen genel anestezi uygulamaları uzun süreli işlemlerin güvenle uygulanabilmesine ve tek seansta tüm diş tedavilerinin yapılabilmesine olanak tanıyarak çocuklarda yaşam kalitesini oldukça yükseltmektedir. ${ }^{4}$ Ancak genel anestezi uygulamaları çeşitli solunum, dolaşım ve alerji gibi yaşamı tehdit edici komplikasyonlar nedeniyle mortalite riski taşımaktadır. Ayrıca operasyon sonrası ağrı, bulantı, kusma, uyku hali veya halsizlik gibi şikâyetlere de neden olabilmektedir. ${ }^{3,5-7}$ Bütün bu dezavantajları nedeni ile genel anestezi hastalarda ve ebeveynlerde merak ve anksiyeteye neden olabilmektedir. ${ }^{8} \mathrm{Bu}$ anksiyete, ebeveynlerin çocuklarının genel anestezi altında tedavi prosedürlerine devam edip etmeme kararlarını ve tedavi seçeneklerini etkileyebilmektedir. ${ }^{9}$

Ebeveynlerin genel anestezi ile ilgili kaygılarının giderilmesinde uygulanacak işlemler hakkında yeterli bilgi ve farkındalığa sahip olması oldukça önemlidir. Yetersiz bilgi dışında ebeveynlerin genel anestezi ile ilgili tutum ve anksiyeteleri cinsiyet, eğitim, önyargllı kavramlar, medya ve daha önce genel anesteziye maruz kalma gibi çeşitli faktörlerden etkilenmektedir. Bu faktörler ile ilgili bilgiler, hekimlerin ebeveynlerin endişelerini anlamasına yardımcı olabilir ve böylece hekimler, ebeveynleri genel anestezi ile ilgili riskler ve faydalar konusunda daha etkili bir şekilde bilgilendirebilir. ${ }^{9}$ Bu sayede ebeveynlerin ve çocukların kaygı düzeyleri azaltılabilir. ${ }^{10}$

Genel anestezi uygulamaları ile ilgili bilgi düzeyini değerlendiren çalışmalar ağırlıklı olarak ameliyat öncesi hastalara uygulanan anket sonuçlarına dayanan çalışmalardır. ${ }^{11-13}$ Çok az sayıda çalışma pediatrik dental tedavilerde genel anestezi uygulamaları ile ilgili ebeveyn bilgi düzeyini değerlendirmektedir. ${ }^{14}$ Ancak bildiğimiz kadarıyla Türkiye'de bu konuda yapılmış bir çalışma yoktur. Bu çalışmanın amacı genel anestezi altında dental tedavileri yapılacak çocukların ebeveynlerinin genel anestezi ile ilgili bilgi düzeylerini değerlendirmek ve preoperatif anksiyetelerinin şiddetini Vizüel Analog Skala (VAS) kullanarak ölçmektir.

\section{Gereç ve Yöntem}

Bu çalışma Mersin Üniversitesi Klinik Araştırmalar Etik Kurulu'nun 2018/47 sayılı etik onayı alınarak yapılmıştır. Anket uygulamaları Erciyes Üniversitesi Diş Hekimliği Fakültesi'nde 01 Mart - 1 Ağustos 2018 tarihleri arasında yapılmıştır. Çalışma Helsinki Deklarasyonu Prensipleri'ne uygun olarak yapılmıştır ve genel anestezi altında dental tedavileri yapılacak çocuk hastaların ebeveynlerine anket hakkında bilgilendirildikten sonra anket formu verilmiş ve doldurmaları sağlanmıştır.

Bu çalışmaya 18 yaşından büyük, araştırmaya katılmayı kabul eden ve Erciyes Üniversitesi'ne dental tedaviler için başvuran ve genel anestezi endikasyonu koyulan çocuk hastaların ebeveynleri dâhil edilmiştir. Anketi tamamlamayan, çalışmaya katılmayı kabul etmeyen ve okuma-yazma bilmeyen ebeveynler çalışmaya dâhil edilmemiştir.

Standart Anestezi Öğrenme Testi (SALT) modifiye edilip, sadece genel anestezi bilgi seviyesini sorgulayan bir anket formu ile ebeveynlerin bilgi seviyeleri tespit edilmiştir. ${ }^{15}$ Üç bölümden oluşan bu modifiye anketin birinci bölümünde cinsiyet, yaş, çocuk sayısı, eğitim durumları, önceki anestezi deneyimi ve anestezi alacak çocuğun yaşı ve cinsiyeti sorgulanarak elde edilen kişisel bilgiler, ikinci bölümde genel anestezi ile ilgili çoktan seçmeli sorular ve üçüncü bölümde ise doğru ve yanlış seçeneklerinden oluşan sorular yer 
almaktaydı. ìkinci ve üçüncü bölümde ebeveynlerin genel anestezi hakkındaki bilgileri sorgulanmıştır. Ayrıca ebeveynlerin anksiyete düzeyi, çocukları ameliyathaneye alındıktan hemen sonra modifiye VAS kullanılarak değerlendirilmiştir. ${ }^{16,17}$ VAS, ağrı, anksiyete, mide bulantısı, yorgunluk, nefes darlığı ve açlık gibi fenomenleri ölçmek için hem tanımlayıcı hem de deneysel çalışmalarda kullanılmışıır. ${ }^{17}$ Çalışmada kullanılan modifiye VAS skalasında skor arttıkça anksiyete düzeyi azalmaktadır (şekil 1).

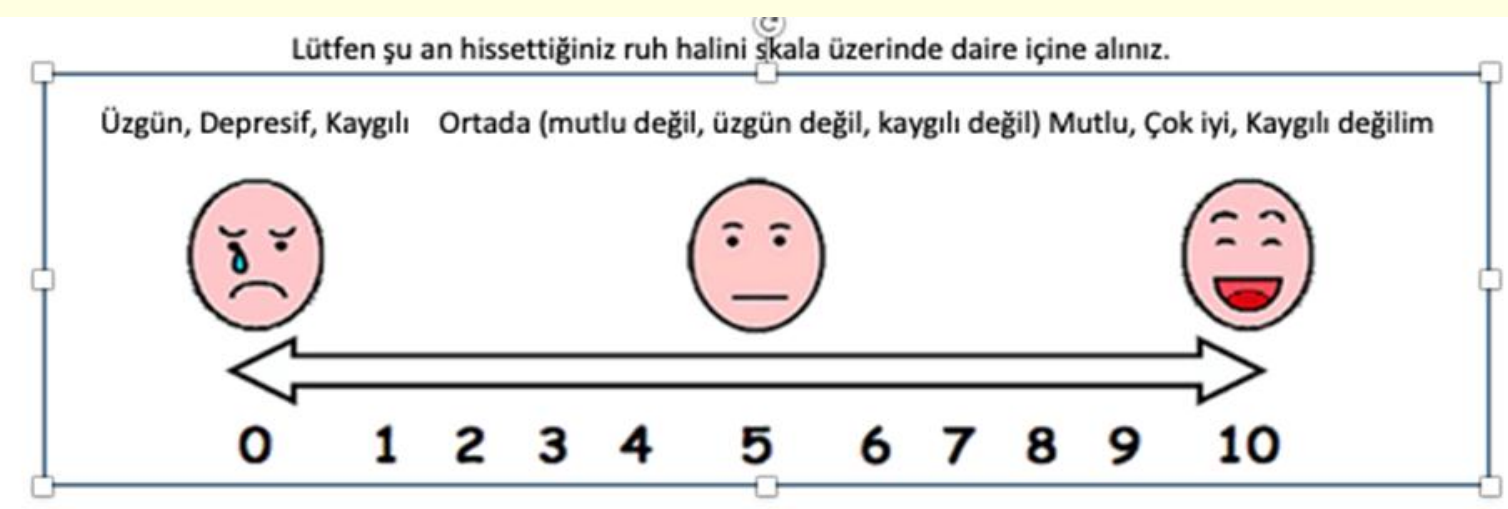

Şekil 1. Modifiye Vizüel Analog Skala (VAS)

Verilerin istatistiksel analizinde grupların değerleri için deskriptif ve sıklık testleri uygulanmıştır. Normal dağıım göstermeyen parametreler için Shapiro-Wilk testi kullanılmıştır. íkili karşslaştırılan parametreler arasındaki ilişkiyi incelemek için Mann Whitney $U$ testi ve çoklu karşılaştırılan parametreler arasındaki ilişkiyi incelemek için Kruskal Wallis testi yapılmıştır. Tüm verilerde istatistiksel anlamlılık $p<0,05$ düzeyinde değerlendirilmiştir.

\section{Bulgular}

Genel anestezi altında dental tedavileri yapılan 242 çocuğun ebeveyni çalışmaya dâhil edildi ancak çalışmaya katılan 7 çocuğun ebeveyni anket formunu eksik doldurdukları için çalışma dışı bırakıldı. Anketi 148 kadın $(\% 63,0), 87$ erkek $(\% 37,0)$ olmak üzere toplam 235 ebeveyn tamamladı. Anketi cevaplayan ebeveynlerin 147 'si $(\% 62,6)$ anne, 86'sı $(\% 36,6)$ baba ve 2'si $(\% 0,9)$ diğer ebeveynlerden oluşmaktaydı. Katılımcılar en fazla 31-40 yaş aralığında idi (\%54,9). Eğitim durumlarına göre anketi cevaplayan ebeveynlerin \%39,1'ini lise mezunları oluşturuyordu ( $n=92)$, geri kalanını sırasıyla, üniversite $(\% 28,5, n=67)$, ortaokul $(\% 16,6, \mathrm{n}=39)$ ve ilkokul mezunları $(\% 15,7, \mathrm{n}=37)$ oluşturmaktaydı. Çocukların yaş ortalaması $5,2 \pm 2,3$ yıl idi ve 99'u $(\% 42,1)$ kadın ve 136 'sı $(\% 57,9)$ erkekti. Ebeveynlerin \%64,3'ünün daha önceden anestezi deneyimi vardı. Katılımcıların demografik özellikleri ve önceki anestezi deneyimleri Tablo 1 'de verilmiştir.

Tablo 1. Ebeveynlerin sosyo-demografik özellikleri ve daha önceki genel anestezi deneyimleri

\begin{tabular}{llcc}
\hline & & $\mathbf{n : 2 3 5}$ & $\%$ \\
\hline Anketi cevaplayan & Anne & 147 & 62,6 \\
ebeveyn & Baba & 86 & 36,6 \\
& Diğer & 2 & 0,8 \\
Ebeveyn cinsiyet & Kadın & 148 & 63,0 \\
& Erkek & 87 & 37,0 \\
Ebeveyn yaş aralığı & $20-30$ & 67 & 28,5 \\
& $31-40$ & 129 & 54,9 \\
& $41-50$ & 36 & 15,3 \\
Çocuk sayısı & $50>$ & 3 & 1,3 \\
& 1 & 44 & 18,7 \\
& 2 & 111 & 47,2 \\
& 3 & 66 & 28,1 \\
& 4 ve üzeri & 14 & 6,0 \\
\hline
\end{tabular}




\begin{tabular}{llcc}
\hline Anketi cevaplayan & ilkokul & 37 & 15,7 \\
ebeveynin eğitimi & Ortaokul & 39 & 16,6 \\
& Lise & 92 & 39,1 \\
& Üniversite & 67 & 28,6 \\
Eşinin eğitimi & ilkokul & 46 & 19,6 \\
& Ortaokul & 46 & 19,6 \\
& Lise & 77 & 32,8 \\
\multirow{3}{*}{ Genel anestezi deneyimi i } & Üniversite & 66 & 28,0 \\
& Evet & 151 & 64,3 \\
Çocuğun cinsiyeti & Hayır & 84 & 35,7 \\
& Kadın & 99 & 42,1 \\
& Erkek & 136 & 57,9 \\
\hline
\end{tabular}

Ebeveynlerin genel anestezi bilgisi ile ilgili tüm bulgular Tablo 2'de özetlenmiştir. Ebeveynlerin \%80,4'ü çocuğun genel anestezisi öncesinde yemek yediğinde ameliyatın ertelendiğini, \%56,6'sı genel anestezinin çocuklarda maske yardımı ile çocuğa gaz solutularak başlatıldığını ve $\% 55,7$ 'si ise genel anestezi öncesi damar yolunun sıvı girişi yapılmasına olanak sağlamak için açıldığını belirtti. Katılımcıların \%48,5'i anestezi uzmanının anestezi alanında eğitim almış teknisyen olduğunu bildirirken sadece \%35,7'si anestezi uzmanının doktor olduğunu ifade etti (Tablo 2).

Tablo 2. Ebeveynlerin genel anestezi hakkındaki bilgisi

\begin{tabular}{|c|c|c|c|}
\hline & & $\mathrm{n}: 235$ & $\%$ \\
\hline \multirow{5}{*}{$\begin{array}{l}\text { Doktorlar genel anestezi } \\
\text { altında diş tedavisi } \\
\text { yapılacak çocuklardan } \\
\text { nasıl davranmalarını } \\
\text { beklerler? }\end{array}$} & Ameliyat olmaktan kaçmalarını & 14 & 5,9 \\
\hline & Aileleri ile ameliyat ve genel anestezi hakkında konuşmalarını & 163 & 69,4 \\
\hline & Ameliyat öncesi bir şeyler yemelerini & 22 & 9,4 \\
\hline & Korksalar da korkmamış gibi davranmalarını & 31 & 13,2 \\
\hline & Bilmiyorum & 5 & 2,1 \\
\hline \multirow{5}{*}{$\begin{array}{l}\text { Çocuğunuz genel } \\
\text { anestezi öncesi bir } \\
\text { şeyler yerse: }\end{array}$} & Ameliyattan önce dişlerini fırçalaması gerekir & 23 & 9,8 \\
\hline & Ameliyat sonrası kendini daha iyi hisseder & 17 & 7,2 \\
\hline & Ameliyatın ertelenmesi gerekir & 192 & 81,7 \\
\hline & Sadece meyve veya sebze yiyebilir. & 3 & 1,3 \\
\hline & Bilmiyorum & 0 & 0,0 \\
\hline \multirow{5}{*}{$\begin{array}{l}\text { Genel anestezi öncesi } \\
\text { çocukların genellikle } \\
\text { korkmasının sebebi } \\
\text { aşağıdakilerden } \\
\text { hangisidir? }\end{array}$} & Doktorunu göremediği için & 5 & 2,2 \\
\hline & Zarar göreceğini düşündüğü için & 189 & 80,4 \\
\hline & Ebeveynleri ile birlikte olduğu için & 8 & 3,4 \\
\hline & Yukarıdakilerin hepsi doğru & 33 & 14,0 \\
\hline & Bilmiyorum & 0 & 0,0 \\
\hline \multirow{5}{*}{$\begin{array}{l}\text { Bir çocukta genel } \\
\text { anestezi nasıl başlatılır? }\end{array}$} & Çocuğun nefesini tutması ile başlatılır & 8 & 3,4 \\
\hline & Çocuğun kan vermesi ile başlatılır & 42 & 17,9 \\
\hline & Maske yardımı ile çocuğa gaz solutulması ile başlatııır & 133 & 56,6 \\
\hline & Bir bardak ilaç içeren Coca-Cola ile başlatılır & 43 & 18,3 \\
\hline & Bilmiyorum & 9 & 3,8 \\
\hline \multirow{5}{*}{$\begin{array}{l}\text { Genel anestezi öncesi } \\
\text { damar yolu (damar içi, } \\
\text { intravenöz) neden açılır? }\end{array}$} & Enfeksiyonu önlemek için & 6 & 2,6 \\
\hline & Doktorun hastaya sıvı girişi yapmasına olanak sağlamak için & 131 & 55,7 \\
\hline & Hastaya oksijen vermek için & 7 & 3,0 \\
\hline & Anestezinin etkilerini izlemek için & 91 & 38,7 \\
\hline & Bilmiyorum & 0 & 0,0 \\
\hline \multirow{5}{*}{$\begin{array}{l}\text { Genel anesteziden önce } \\
\text { çocuklar nasıl daha } \\
\text { sakin hale getirilebilir? }\end{array}$} & Hafif sakinleştirici ilaç verilerek & 128 & 54,5 \\
\hline & Doktorun ameliyatta yapılacak çok zor işlemleri açıkça anlatması ile & 83 & 35,3 \\
\hline & Kahvaltı verilerek & 5 & 2,1 \\
\hline & A ve $C$ şıkları doğru & 19 & 8,1 \\
\hline & Bilmiyorum & 0 & 0,0 \\
\hline \multirow[t]{5}{*}{ Anestezi uzmanı kimdir? } & Anestezi alanında eğitim almış hemşire & 32 & 13,6 \\
\hline & Doktor & 84 & 35,7 \\
\hline & Doktor Yardımcısı & 3 & 1,3 \\
\hline & Anestezi alanında eğitim almış teknisyen & 114 & 48,5 \\
\hline & Bilmiyorum & 2 & 0,9 \\
\hline \multirow{4}{*}{$\begin{array}{l}\text { Hangi hastaların } \\
\text { ameliyat sırasında bilinci } \\
\text { yoktur? }\end{array}$} & Lokal anestezi uygulanan hastalar & 8 & 3,4 \\
\hline & Genel anestezi uygulanan hastalar & 165 & 70,2 \\
\hline & Ameliyat öncesi ilaç verilmeyen hastalar & 12 & 5,1 \\
\hline & A ve $B$ şıkları doğru & 49 & 20,9 \\
\hline
\end{tabular}




\begin{tabular}{|c|c|c|c|}
\hline & Bilmiyorum & 1 & 0,4 \\
\hline \multirow{5}{*}{$\begin{array}{l}\text { Genel anestezi hakkında } \\
\text { doğru şıkkı işaretleyiniz? }\end{array}$} & Sadece genel cerrah tarafından uygulanabilir & 73 & 31,0 \\
\hline & Vücudun sadece belirli bir alanında uyuşukluk sağlar & 20 & 8,5 \\
\hline & Çocuğun yapılan işlemleri hatırlamamasını sağlar & 105 & 44,7 \\
\hline & Genellikle çok risklidir & 35 & 14,9 \\
\hline & Bilmiyorum & 2 & 0,9 \\
\hline \multirow{5}{*}{$\begin{array}{l}\text { Cerrahi hastalarda genel } \\
\text { anestezi neden } \\
\text { gereklidir? }\end{array}$} & Ameliyathanede doktor-hemşire arasındaki konuşmaları duymamaları için & 7 & 3,0 \\
\hline & Hastanın ameliyat boyunca ağrı hissetmemesi için. & 125 & 53,2 \\
\hline & Cerrahi işlemler sırasında hastada oluşacak stresi engellemek için. & 17 & 7,2 \\
\hline & $B$ ve $C$ şıkları doğrudur. & 84 & 35,7 \\
\hline & Bilmiyorum & 2 & 0,9 \\
\hline \multirow[b]{2}{*}{$\begin{array}{l}\text { Genel anestezi sırasında } \\
\text { çocuğun ameliyatı } \\
\text { görememesi için } \\
\text { çocuğun göz kapakları } \\
\text { bantla kapatılmalıdır. }\end{array}$} & Doğru & 53 & 22,6 \\
\hline & Yanlış & 182 & 77,4 \\
\hline Ameliyat öncesinde & Doğru & 201 & 85,5 \\
\hline $\begin{array}{l}\text { anesteziyi bir çocuğa } \\
\text { açıklamak gereklidir ve } \\
\text { bu "uykun gelecek ve } \\
\text { uyuyacaksın" şeklinde } \\
\text { yapılabilir. }\end{array}$ & Yanlış & 34 & 14,5 \\
\hline
\end{tabular}

Çalışmada ebeveynlerin anksiyetesi için VAS skorları çocukları ameliyathaneye alındıktan hemen sonra kaydedildi. Daha önce genel anestezi alan ve almayan çocukların ebeveynlerinin anksiyete skorları arasında anlamlı fark bulunamadı ( $p=0,245)$. Ebeveynlerin eğitim düzeyi ile kaygı skorları arasında anlamlı bir fark yoktu ( $p=0,769)$. Çocuk sayısı ile ebeveynlerin anksiyete skorları karşılaştırıldığında da anlamlı bir farklılık bulunamadı $(p=0,242)$. Ebeveynlerin cinsiyeti ile VAS skorları karşılaştırıldığında kadınların skorlarının erkeklere göre daha düşük olduğu, dolayısıyla kadınların anksiyete düzeyinin erkeklere göre anlamlı olarak daha yüksek olduğu bulundu $(p=0,004)$. Ebeveynlerin yaş aralığı ile VAS anksiyete düzeyleri arasında istatistiksel olarak anlamlı bir fark olduğu saptandı $(p<0,001)$. Yaş arttıkça VAS skorlarının arttığı ve anksiyete düzeyinin azaldığı belirlendi (Tablo 3-7).

Tablo 3. Ebeveyn cinsiyeti ile kaygı durumunun (VAS) karşılaştırılması

\begin{tabular}{|c|c|c|c|c|}
\hline & Kadın & Erkek & Toplam & \\
\hline & $\mathrm{n}: 148$ & $\mathrm{n}: 87$ & $\mathrm{n}: 235$ & $\mathbf{P}$ \\
\hline VAS (0-10) (Ort $\pm S S)$ & $4,64 \pm 2,47$ & $5,62 \pm 2,67$ & $5,01 \pm 2,59$ & 0,004 \\
\hline
\end{tabular}

Tablo 4. Genel anestezi deneyimi ile kaygı durumunun (VAS) karşılaştırılması

\begin{tabular}{lccc}
\hline & Var & Yok & Toplam \\
& $\mathrm{n}: 151$ & $\mathrm{n}: 84$ & $\mathrm{n}: 235$ \\
\hline VAS (0-10) (Ort \pm SS) & $5,17 \pm 2,54$ & $4,71 \pm 2,64$ & $5,01 \pm 2,59$ \\
\hline * $\mathrm{p}<0,05$, Ort $\pm S S:$ Ortalama \pm Standart sapma & & 0,245 \\
\hline
\end{tabular}

Tablo 5. Ebeveyn yaş aralığı ile kaygı durumunun (VAS) karşılaştırılması

\begin{tabular}{|c|c|c|c|c|c|}
\hline & $20-30$ yaş & $31-40$ yaş & $41-50$ yaş & 50 yaş ve üzeri & \\
\hline & $\mathrm{n}: 67$ & $\mathrm{n}: 129$ & $\mathrm{n}: 36$ & $\mathrm{n}: 3$ & $\mathbf{P}$ \\
\hline VAS (0-10) (Ort $\pm S S)$ & $4,55 \pm 2,67$ & $4,93 \pm 2,53$ & $5,86 \pm 2,25$ & $8,00 \pm 3,46$ & 0,000 \\
\hline
\end{tabular}

$*_{\mathrm{p}}<0,05$, Ort $\pm S S:$ Ortalama \pm Standart sapma

Tablo 6. Ebeveyn eğitim düzeyi ile kaygı durumunun (VAS) karşılaştırılması

\begin{tabular}{|c|c|c|c|c|c|}
\hline & ìlkokul & Ortaokul & Lise & Üniversite & \\
\hline & $\mathrm{n}: 37$ & $\mathrm{n}: 39$ & $\mathrm{n}: 92$ & $\mathrm{n}: 67$ & $\mathbf{P}$ \\
\hline VAS (0-10) (Ort $\pm S S)$ & $4,78 \pm 2,63$ & $5,00 \pm 2,20$ & $5,06 \pm 2,42$ & $5,05 \pm 2,99$ & 0,769 \\
\hline
\end{tabular}

${ }^{*} \mathrm{p}<0,05$, Ort $\pm S S:$ Ortalama \pm Standart sapma 
Tablo 7. Çocuk sayısı ile kaygı durumunun (VAS) karşılaştırılması

\begin{tabular}{lccccc}
\hline & $\mathbf{1}$ Çocuk & $\mathbf{2}$ Çocuk & 3 Çocuk & 4 ve fazla \\
& $\mathrm{n}: 44$ & $\mathrm{n}: 111$ & $\mathrm{n}: 66$ & $\mathrm{n}: 14$ & $\mathbf{P}$ \\
\hline VAS (0-10) (Ort \pm SS) & $4,22 \pm 2,68$ & $5,15 \pm 2,44$ & $5,22 \pm 2,68$ & $5,28 \pm 2,70$ & 0,242 \\
\hline
\end{tabular}

${ }^{*} p<0,05$, Ort $\pm S S:$ Ortalama \pm Standart sapma

\section{Tartışma}

Tıp alanında uzun yıllardır kullanılıyor olmasına rağmen genel anestezi diş hekimliğinde son yıllarda sık başvurulan bir yöntem olmuştur. Ancak genel anestezi prosedürü, hastaneye yatış, donanımlı bir ortam ve ekipman, farmakolojik ajanlar ve eğitimli bir genel anestezi ekibi gerektirmektedir. ${ }^{3}$ Çocuklardaki genel anestezi altında gerçekleştirilecek planlı veya acil bir cerrahi operasyon ve hastaneye yatış, sadece çocuk için değil tüm aile için oldukça stresli bir işlemdir ve ebeveynlerinin çoğu bu işlemlerde, artan düzeyde kaygı yaşamaktadır. ${ }^{15}$ Hastaneye yatış ve cerrahi işlemin yanı sıra, ameliyatın hasta için taşıdığı anlam, ameliyat öncesi, sırası ve sonrasında yaşanabilecek durumlara yönelik bilgi yetersizliği, olası olumsuz sonuçlar, ameliyat sonrası ağrı ve çeşitli tıbbi uygulamalar anksiyeteye neden olabilmektedir. ${ }^{18}$

Artmış ebeveyn kaygısı, çocukların tıbbi prosedürlerle başa çıkmasını etkileyebilmektedir. ${ }^{15}$ Ebeveynlerin korkularını önlemek ve kaygılarının gidermek için en iyi yol bilgilendirmedir. Dolayısıyla hastaların ve ebeveynlerin genel anestezi uygulamaları hakkındaki bilgi düzeylerinin arttırılması, ameliyat anksiyetesinin giderilmesi ve ameliyat sonrası bakım ve niteliğin arttırılması açısından oldukça önemlidir. ${ }^{19}$ Literatürde de ameliyat öncesi eğitim gereksinimi fazla olan hastaların anksiyete düzeyinin fazla olduğu ve sağılı sorunlarıyla ilgili hastaların yeterli ve kapsamlı bilgilendirilmesinin hasta-hekim arasındaki uyumu arttırarak komplikasyonları azalttığı gösterilmiştir. ${ }^{20}$ Daha önce yapılan çalışmalarda genellikle acil, günübirlik ya da planlı ameliyat geçirecek hastaların, ebeveynlerin ve genel halkın anestezi uygulamaları ile ilgili bilgi düzeyi ve anksiyetesi araştııımıştır. Genel anestezi altında dental tedavi görecek çocukların ebeveynlerinin anksiyetelerini ve bilgi düzeyini değerlendiren çalışmalar ise literatürde oldukça sınırlıdır. ${ }^{8,14,21} \mathrm{Bu}$ çalışmada da genel anestezi altında dental tedavileri yapılacak çocukların ebeveynlerinin kaygı ve bilgi düzeyleri değerlendirilmiştir.

Çalışmamızda ebeveynlerin cinsiyet, eğitim, yaş, çocuk sayısı ve genel anestezi deneyimi gibi demografik verilerinin kaygı düzeyleri üzerine etkileri değerlendirilmiş̧ir. Literatürde eğitim durumunun anksiyete düzeyini etkilemediğini bildiren çalışmalar bulunduğu gibi, eğitim seviyesi düştükçe anksiyetenin arttığını bildiren çalışmalar da bulunmaktadır. ${ }^{22-25}$ Çalışmamızda ise ebeveynlerin eğitim düzeyi ile anksiyete skorları arasında istatistiksel olarak anlamlı bir sonuç elde edilmese de, ilkokul mezunlarının anksiyetelerinin ortaokul, lise ve üniversite mezunlarına göre daha fazla olduğu bulunmuştur. Bu sonuçlar eğitim düzeyi arttıkça anksiyete seviyelerinin azaldığını düşündürmektedir. Eğitim düzeyi düşük olan ebeveynlerin çocuklarına yapılacak işlemleri tam anlayamaması ya da uygulanacak tedaviler ile ilgili verilen bilgileri kavramada zorluk yaşamaları anksiyete düzeylerinin artmasına sebep olmuş olabilir. Eğitim düzeyi yüksek olanlarda ise anksiyete düzeylerinin azalması, konu ile ilgili yeterince bilgiye sahip olmaları ile ilgili olabilir.

Gürol ve Binici tarafından yapılan çalışmada daha önce farklı nedenlerle hastaneye yatmış olan çocukların annelerinin daha az, hastaneye yatma deneyimi yaşamamış annelerin ise daha fazla anksiyetesinin olduğu bulunmuştur. ${ }^{25}$ Litman ve ark. tarafından yapılan çalışmada da çocukları daha önce ameliyat olmuş annelerin anksiyete skorları daha düşük çıkmıştır. ${ }^{26}$ Bu çalışmaların aksine, çalışmamızda ebeveynlerin anksiyete skorları ile genel anestezi deneyimi arasında anlamlı bir fark gözlenmemiştir. Ancak daha önce anestezi deneyimi olmayan ebeveynlerin anestezi deneyimi olan ebeveynlere göre istatistiksel olarak anlamlı olmasa da daha endişeli oldukları saptanmıştır. Bunun, önceden herhangi bir nedenle genel 
anestezi deneyimi yaşamış ebeveynlerin, hastane ortamını ve nasıl bir durumla karşılaşabileceklerini bilmelerinden kaynaklandığı düşünülmektedir.

Daha önce yapılan çalışmalar cinsiyet ile anksiyete arasındaki ilişki ile ilgili farklı sonuçlar bildirmiştir. Bazı çalışmalarda anksiyete düzeylerinde cinsiyet açısından farklıık gözlenmezken, bazı çalışmalarda kadınlarda preoperatif dönemde anksiyete düzeylerinin daha yüksek olduğu belirtilmektedir. ${ }^{24,27}$ Çalışmamızda Moerman ve ark. tarafından yapılan çalışmanın bulguları ile uyumlu olarak, kadınlardaki modifiye VAS skorlarının anlamlı olarak daha düşük olduğu ve dolayısyla anksiyete düzeylerinin erkeklere göre anlamlı olarak daha yüksek olduğu gözlenmiştir. ${ }^{27}$ Shevde ve Panagopoulos kadınların erkeklere göre daha endişeli olmasını, kadınların anksiyete, korku, endişe gibi duygularını daha rahat ifade edebiliyor olmalarına bağlamıştır. ${ }^{28}$ Badner ve ark. ise bu durumu kadınlarda ailelerinden ayrılmaya bağlı anksiyetenin daha yüksek olması ile açıklamıştır. ${ }^{29}$

Başbakkal ve ark. ile Günay ve ark. tarafından yapılan çalışmaların bulguları ile uyumlu olarak, çalışmamızda çocuk sayısının ebeveynlerin anksiyete düzeylerini etkilemediği bulunmuştur. ${ }^{30,31}$ Bizim çalışmamızın bulgularının aksine, Gürol ve Binici tarafından yapılan çalışmada annelerin sahip oldukları çocuk sayısı ile durumluk anksiyete ölçeğinden aldıkları puan ortalamaları arasında istatistiksel olarak anlamlı bir ilişki bulunmuştur. ${ }^{25}$ Aynı çalışmada daha fazla çocuğa sahip annelerin daha yüksek anksiyete puanına sahip olduğu bildirilmiş ve ailelerin evde bakmakla yükümlü oldukları başka bir çocuğun olmasının ebeveynler için stres kaynağı olabileceği vurgulanmıştır. ${ }^{25}$

Çalışmamızda ebeveyn yaşının anksiyeteyi etkilediği ve yaşın artmasıyla modifiye VAS skorlarının arttığı ve anksiyetenin azaldığı belirlenmiştir. Literatürde ameliyat öncesi anksiyetenin gençlerde yaşlılara kıyasla yüksek olduğu bildirilmiştir ve bu durum yaşlılarda baskın olan kadercilik eğiliminin ve kültürel faktörlerin, yaşam streslerine daha kolay dayanmalarına neden olması ile açıklanmıştır. ${ }^{12}$ Çalışma bulgularımııı aksine, Oğuzalp ve ark. tarafından yapılan çalışmada ebeveyn yaşı ve ebeveynlerin durumluk ve sürekli anksiyete puanları arasında istatistiksel olarak anlamlı bir ilişki bulunmamıştır. ${ }^{23}$ Sonuçlar arasındaki bu farklılıklar, araştırma gruplarının özelliklerine, çalışmalardaki metodolojik farklılıklara ve anksiyeteyi etkileyebilecek faktörler açısından toplumlar arasındaki farklılıklara bağlı olabilir.

Miller ve ark. tarafından yapılan çalışmada hastanede yatan ve genel anestezi altında cerrahi işlem yapılacak olan 85 çocuğun ebeveynine SALT uygulanarak lokal ve genel anestezi ile ilgili ebeveyn bilgisi değerlendirilmiştir. ${ }^{15}$ SALT özellikle anestezi hakkında bilgiyi ölçmektedir. Bu çalışmada ebeveynlerin sadece genel anestezi ile ilgili bilgisi araştıııldığı için SALT modifiye edilerek kullanılmıştır. Çalışmamızdan elde edilen sonuçlar, ebeveynlerin yaklaşık \%20'sinin genel anesteziden ne kadar önce yeme-içmenin kesileceğini bilmediğini, \%43,4'ünün genel anestezinin nasıl başlatıldığını bilmediğini ve \%44,3'ünün ise genel anestezi öncesi damar yolunun neden açıldığını bilmediğini göstermiştir. Ayrıca ebeveynlerin yaklaşık \%65'i anestezi uzmanın doktor olmadığını düşünmektedir. Bu sonuçlar ebeveynlerin pediatrik dental tedavilerde sıkça uygulanan genel anestezi uygulamaları ile ilgili yeterince bilgilerinin olmadığını ve sağlık çalışanlarının ameliyat öncesi ebeveynlerin korku ve endişelerini gidermek için daha fazla bilgilendirme yapmaları gerektiğini göstermektedir.

Çalışmamııın çeşitli sınırlııkları bulunmaktadır. Daha önce yapılan bazı çalışmalarda anksiyeteyi değerlendirmek için kan basıncı, nabız gibi fizyolojik parametreler ve epinefrin, norepinefrin, kortizol gibi nöroendokrinolojik parametreler kullanılmıştır. ${ }^{32} \mathrm{Bu}$ çalışmada ise ebeveyn anksiyetesini değerlendirmek için sadece VAS skalası kullanılmıştır. Veriler sadece tek bir hastanedeki ebeveynlerden toplanmıştır. Bu çalışmada ebeveynlerin genel anestezi ile ilgili korku ve endişelerin nedeni ve neler olduğu değerlendirilmemiştir. 


\section{Sonuç}

Çalışmamııın sonuçları ebeveynlerin pediatrik dental tedavilerde sıkça uygulanan genel anestezi uygulamaları ile ilgili değişen düzeylerde preoperatif anksiyeteye sahip olduklarını ve anksiyetenin ebeveyn cinsiyeti ve yaşı gibi demografik özelliklerden etkilendiğini göstermiştir. Ayrıca bu çalışma ebeveynlerin pediatrik dental tedavilerde sıkça uygulanan genel anestezi uygulamaları ile ilgili bilgilerinin yeterli olmadı̆̆ını ve sağlık çalışanlarının ameliyat öncesi ebeveynlerin korku ve endişelerini gidermek için daha fazla bilgilendirme yapmalarının gerektiğini göstermektedir.

\section{Bilgi}

Herhangi bir çıkar çatışması bulunmamaktadır.

\section{Etik Onay}

Mersin Üniversitesi Klinik Araştırmalar Etik Kurulu'ndan (2018/47) etik onay alınmıştır.

\section{Araştırmacı Katkı Oranı Beyanı}

Ayşe Özcan Küçük: Araştırmanın fikri, tasarımı, organizasyonu, veri toplama, bulguların analiz ve yorumu, kaynak tarama, makale yazımı, eleştirel okuma.

Ebru Delikan: Araştırmanın fikri, tasarımı, veri toplama, bulgularının analiz ve yorumu, kaynak tarama, eleştirel okuma.

Hüsniye Gümüş: Araştırmanın fikri, tasarımı, veri toplama, bulgularının analiz ve yorumu, kaynak tarama, eleştirel okuma.

\section{Kaynaklar}

1. Şahin D. Genel Anestezi Altında Diş Çekimi Yapılan Mental Retarde Hastalarda Deneyimlerimiz. Ata Diş Hek Fak Derg 2011;2011(1):10-4.

2. Şimşek T, Yılmaz M. Çocuk Hastalardaki Dental Girişimlerde Genel Anestezi ile Sedasyon Tekniğinin Retrospektif Karşılaştırılması. Kocaeli Tıp Dergisi 2017;6(1):59-62.

3. Bakkal M. Çocuklarda genel anestezi altında yapılan dental tedavilerin değerlendirilmesi. Bezmialem Science 2018;6(4):248-52

4. Rashewsky S, et al. Time and cost analysis: pediatric dental rehabilitation with general anesthesia in the office and the hospital settings. Anesth Prog 2012;59(4):147-53.

5. Nkansah PJ, Haas DA, Saso MA. Mortality incidence in out-patient anaesthesia for dentistry in Ontario. Oral Surg Oral med Oral Pathol Oral Radiol Endod 1997;83(6):646-51

6. Atan S, et al. Morbidity following dental treatment of children under in-tubation general anaesthesia in a day-stay unit. Int $J$ Paediatr Dent 2004;14(1):9-16.

7. Bharti N, Batra Yk, Kaur H. Paediatric perioperative car-diac arrest and its mortality: database of a 60-month period from a tertiary care paediatric centre. Eur J Anaesthesiol 2009;26(6):490-5.

8. Balmer R, et al. Anxiety related to dental general anaesthesia: changes in anxiety in children and their parents. Eur J Paediatr Dent 2004;5(1):9-14

9. Koh JH, Daniel P, Bong CL. Parental perception on the effects of early exposure to anaesthesia on neurodevelopment. Anaesthesia 2019;74(1):51-6.

10. Landier $\mathrm{M}$, et al. The position of a written document in preoperative information for pediatric surgery: A randomized controlled trial on parental anxiety, knowledge, and satisfaction. J Pediatr Surg 2018;53(3):375-80.

11. Gençay I, Aydın G. Operasyon planlanan hastalarda anestezi ile ilgili farkındalığın değerlendirilmesi. Kırıkkale Univ Tip Fak Derg 2020;22(2):225-32.

12. Demir A, et al. Anestezi uygulamaları ile ilgili olarak preanestezik değerlendirme sırasında hastalarda yapılan anket çalışması. Türk Anest Rean Der 2009;37(4):225-33.

13. Süren $\mathrm{M}$, et al. Ameliyat Olan Hastaların Anestezi Memnuniyetinin ve Anestezi Bilgilerinin Değerlendirilmesi. Gaziosmanpaşa Tıp Dergisi 2013;5(2):84-90.

14. Khodadadi E, Nazeran F, Gholinia-Ahangar H. Awareness and attitude of parents toward pediatric dental treatment under general anesthesia. J Oral Health Oral Epidemiol 2016;5(1):17-23. 
15. Miller KM, et al. Validation of measures of parents' preoperative anxiety and anesthesia knowledge. Anesth Analg 1999;88(2):251-7.

16. Yılmaz E, Birer Z, Baydur H. Katarakt Ameliyatı Esnasında Uygulanan Terapötik Dokunmanın Kaygı ve Hasta Memnuniyetine Etkisi. J Clin Exp Invest 2016;7(1):52-62.

17. Cline ME, et al. Standardization of the visual analogue scale. Nurs Res 1992;1:378-80.

18. Fındık Ü, Topçu S. Cerrahi Girişime Alını̧̧ Şeklinin Ameliyat Öncesi Anksiyete Düzeyine Etkisi. Hacettepe Üniversitesi Hemşirelik Fakültesi Dergisi 2015;19(2):22-33.

19. Özvurmaz S, Büyükçoban S. Kırsal Bir Bölgede Halkın Anesteziyoloji Uygulamaları Hakkındaki Bilgi ve Korkuları ile ilişkili Faktörlerin Değerlendirilmesi. CBU-SBED 2018;5(3):99-106.

20. Berth H, Petrowski K, Balck F. The Amsterdam Preoperative Anxiety and Information Scale (APAIS)- the first trial of a German version. GMS Psycho-Social Medicine 2007;4:1-8.

21. Hulin J, et al. Development of a decision aid for children faced with the decision to undergo dental treatment with sedation or general anaesthesia. Int J Paediatr Dent 2017;27(5):344-55.

22. Franck LS, Spencer C. Informing parents about anaesthesia for children's surgery: a critical literature review. Patient Educ Couns 2005;59:117-25.

23. Oğuzalp H, Pamuk AG, Öcal T. Günübirlik cerrahide ebeveyn anksiyetesinin ve beklentilerinin değerlendirilmesi. Türk Anest Rean Der 2010;38:208-16.

24. Akdağ $\mathrm{M}$, et al. A multi-centric prospective study: Anxiety and associated factors among par- ents of children undergoing mild surgery in ENT. J Clin Exp Invest 2014;5:206-10.

25. Gürol A, Binici Y. Günübirlik cerrahi geçirecek çocukların annelerinin anksiyete düzeyleri ve etkileyen faktörlerin belirlenmesi. Behçet Uz Çocuk Hast Derg 2017;7(1):29-38.

26. Litman RS, Berger AA, Chhibber A. An evaluation of preoperative anxiety in a population of parents of infants and children undergoing ambulatory surgery. Paediatr Anaesth 1996;6(6):443-7.

27. Moerman N, et al. The Amsterdam Preoperative Anxiety and Information Scale (APAIS). Anesth Analg 1996;82(3):445-51.

28. Shevde K, Panagopoulos G. A Survey of 800 patients' knowledge, attitudes, and concerns regarding anesthesia. Anesth Analg $1991 ; 73(2): 190-8$.

29. Badner NH, et al. Preoperative anxiety: Detection and contributing factors. Can J Anaesth 1990;37(4 Pt 1):444-7.

30. Başbakkal Z, et al. 3-6 yaş grubu çocukların hastaneye yatışa karşı davranışsal tepkileri konusunda verilen eğitimin annelerin anksiyete düzeyi üzerine etkisinin incelenmesi. Anadolu Hemşirelik ve Sağlık Bilimleri Dergisi 2010;12(4):59-65.

31. Günay $O$, et al. Hastanede yatan çocukların annelerinde durumluk ve sürekli anksiyete düzeyi ve ilişkili faktörler. Turk J Public Health 2017:15(3);176-86.

32. Güzel A, et al. Magnetic resonance imaging in children under anesthesia: the relationship between the degree of information provided to parents and parents' anxiety scores. Biomed Res Int 2014;2014:425107. 